\title{
The Economics of Professional Journal Pricing
}

\author{
Michael A. Stoller, Robert Christopherson, \\ and Michael Miranda
}

The problems of excessive inflation and price discrimination in journal pricing continue to plague libraries. In analyzing the causes of the current crisis, the authors review and evaluate previous contributions to the literature on journal pricing with particular emphasis on the three types of price discrimination practiced by journal publishers. The authors suggest that the monopoly power of commercial publishers, combined with a third-party payment system, are at the heart of the problem. They suggest solutions that involve providing appropriate incentives to journal users, adoption of more equitable pricing systems, and employing the potential monopoly purchasing power of library associations to lower prices.

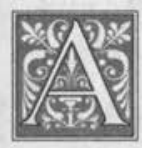

fter more than two decades of extraordinary inflation, professional journal prices continue to increase at rates several times as high as the American economy's overall inflation rate and far higher than the rate of cost increase in the journal publishing industry. ${ }^{1-4}$ Academic economists, marketing researchers, librarians, and paid economic consultants have undertaken economic analyses of journal markets in order to explain the high rates of price increase and the great extent of price discrimination against libraries and United States buyers in general. Some of the researchers subsequently recommended solutions to library administrators, and many of their suggestions are sound and practical. ${ }^{5-9}$ However, a num- ber of the studies are fraught with analytical errors and recommendations that were either economically illogical, impractical, or both. The authors intend to summarize the literature in this area, correct the analysis, and provide practical policy recommendations for library administrators based on what the application of economic principles really tells us about the journal market situation.

\section{The Natural Monopoly Misconception}

Several researchers have analyzed the academic journal industry and labeled it a natural monopoly. Despite the researchers' claims, the academic journal industry is not a natural monopoly. ${ }^{10-12}$ A natural monopoly is an industry in which the cost structure is such that the average pro-

Michael A. Stoller is a Professor of Economics at the State University of New York at Plattsburgh; e-mail: Stollema@splava.cc.Plattsburgh.edu. Robert Christopherson is an Assistant Professor of Economics at the State University of New York at Plattsburgh;e-mail: Christrl@splava.cc.Plattsburgh.edu. Michael Miranda is an Associate Librarian at the Feinberg Library, State University of New York at Plattsburgh. 


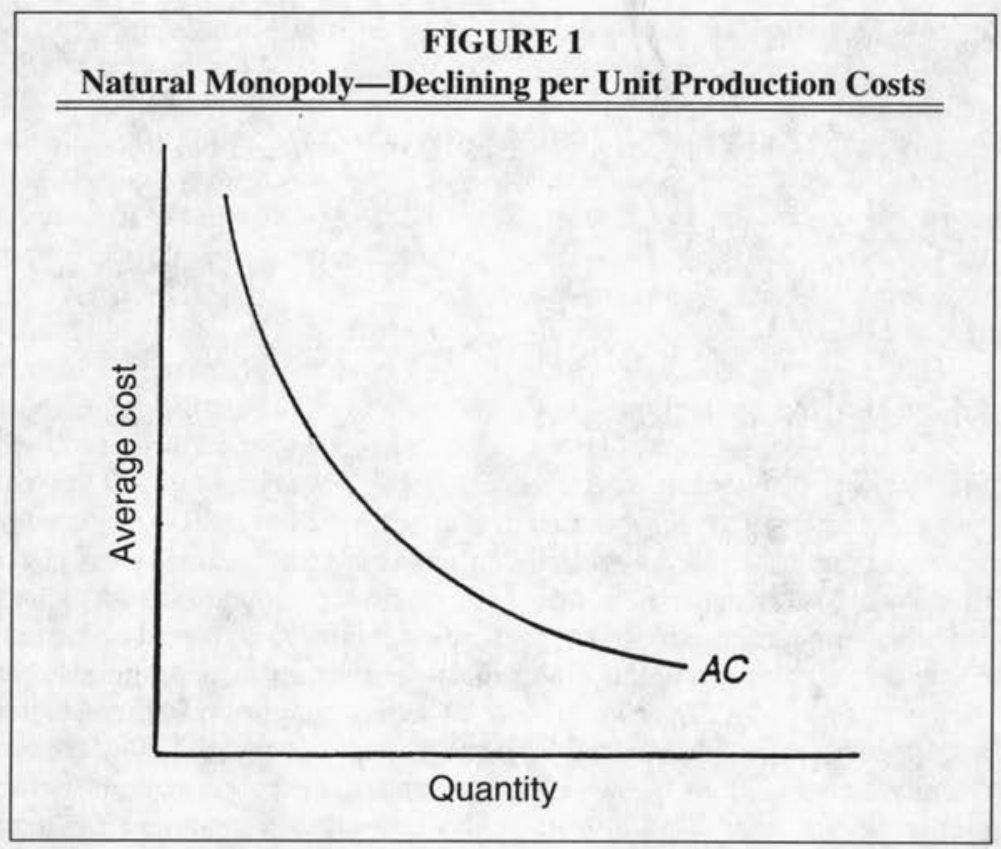

duction cost per unit of the product continues to fall throughout as the firm's production increases (see figure 1). Therefore, one firm can produce the entire industry output more cheaply than having a group of competing firms. Because large firms usually have production cost advantages over small ones, it becomes difficult for small firms to compete and for new firms to enter the industry successfully.

\section{The type of price discrimination practiced by journal publishers is perfectly legal because it is not aimed at putting anyone out of business or disadvantaging a particular group of buyer-resellers through a limited discounting program.}

Public utilities, such as electric, natural gas, and local telephone firms, are the classic examples of natural monopolies. The existence of natural monopolies is the justification for federal, state, and local governments granting public utilities franchised monopolies on the grounds that having more than one local electric, water, telephone, or natural gas supplier would be uneconomical. Competition in these industries would require duplication of transport and connection facilities throughout the service area and would be unnecessarily costly. Hence, state and local governments grant monopoly franchises to utilities and then regulate their prices because there is no competition to keep the prices low.

Certainly there are economies of scale that cause the average cost of journal production to fall as output increases, mostly because of the high initial setup (i.e., first copy) or fixed costs. That is also true for the automobile industry, all of the other publishing industries, or any manufacturing industry for that matter. Typically, cost per unit will fall as the firm expands, but only up to a particular output level. Beyond that production level, per unit cost does not continue to fall and may eventually even increase. There is not a continuously declining cost curve that mandates that there can be only one efficient 
producer of the product, as would exist in a natural monopoly industry, hence the name "natural" monopoly. Firms simply must be large enough to produce efficiently, and in the journal industry, as in most manufacturing industries, the state of technology is such that many firms can operate efficiently, each producing a small percentage of industry output at the minimum average cost (i.e., cost per unit). However, the fact that the technological conditions for a natural monopoly do not exist in the journal publishing industry should not be interpreted to mean that there is no monopoly power in this industry. It is simply not a "natural" condition that is dictated by the state of technology.

\section{Price Discrimination in the Journal Publishing Industry}

A number of researchers have investigated the issue of price discrimination or dual pricing in academic journals. ${ }^{13-17}$ Price discrimination, in its simplest form, is charging different prices to different buyers for the same good or service. Journal pricing, however, is fraught with price discrimination of at least three different varieties, two of them more complex than the simplest form:

1. Commercial and noncommercial journal publishers usually charge academic libraries considerably higher prices (often three times or more as high) than they do individual subscribers for the same quantity of an identical product, i.e., a one-year journal subscription. ${ }^{18}$

2. Western European journal publishers usually charge American buyers considerably higher prices than they do European subscribers for the same quantity of an identical product, after allowing for differences in shipping costs and the risks of exchange rate fluctuations. ${ }^{19-21}$

3. Publishers, particularly commercial firms, charge far higher prices for natural science and en- gineering journals than for journals in other fields, on a per page basis after allowing for any differences in production and shipping costs and costs associated with variation in the frequency of publication. ${ }^{22-24}$

Not surprisingly, economists are interested in these phenomena. In fact, that interest in price discrimination led at least one of this paper's authors to begin doing research on the topic of journal pricing. The authors will explore why price discrimination occurs in journal markets, and why it persists to such a great degree when it does not exist at all or in such a blatant manner in other goods markets.

Several articles in library science journals simply restate the standard economics textbook list of conditions that are conducive to the existence of long-term price discrimination..$^{25}$ The authors assume that all of these conditions are met by the academic journal industry, without studying the situation in depth, because of the long history of price discrimination in this industry. These conditions include the following:

1. There are different markets with substantially different price elasticities of demand (i.e., different degrees of responsiveness to changes in price) that may be identified and kept segregated by the seller (for example, libraries versus individual subscribers or North American customers versus European customers).

2. There are no effective markets for low-price buyers to resell to highprice buyers.

3. Competitors must not be able to undersell the price discriminator in the market segment that is being charged the higher price (i.e., the seller must have monopoly power).

4. The seller's cost of segregating the market must not be greater than the extra revenue generated from price discrimination. 
5. The practice of price discrimination must not breed ill will among consumers.

6. The discrimination must not be illegal.

Certainly most of these conditions must exist to some extent because price discrimination persists, but it is worth studying these conditions individually to see whether there is a possible chink in the publishers' armor through which those being discriminated against may be able to lessen the extent of price discrimination. Some libraries are finding effective ways to deal with this problem (e.g., forming purchasing consortiums or raising their elasticities of demand by sharing journals or purchasing copies of individual articles rather than subscribing to a journal). The assumption that there is no ill will from price discrimination is certainly questionable. The question is whether such ill will can be transformed into an effective weapon against price discrimination.

Edward Dyl implies that price discrimination, as practiced by journal publishers, may be illegal under the prohibitions of the Robinson-Patman Antitrust Act, and he notes that the federal government has never tested this law's provisions on the academic journal industry. ${ }^{26}$ In fact, the Robinson-Patman Act could not possibly apply to journal price discrimination because it is a piece of depression era legislation aimed at protecting small competitors from large ones (most notably from A\&P, the retail giant of the 1930 s). It outlaws price discrimination only to the extent that large buyers cannot be offered discounts that are not available to smaller buyers. The type of price discrimination practiced by journal publishers is perfectly legal because it is not aimed at putting anyone out of business or disadvantaging a particular group of buyer-resellers through a limited discounting program. There is nothing illegal in price discriminating against a group of customers under the RobinsonPatman Act, and it is a very common practice. For example, consider the variety of ticket prices charged by airlines or movie theaters for equal-quality seats.

\section{The Equity Question: Is Price Discrimination Fair?}

Publishers might argue that price discrimination in journal pricing is fair based on the fact that library copies of journals are read much more frequently than individuals' copies and that photocopying from library copies is quite common, with no remuneration to the publisher. Welfare economists, aiming for efficient use of resources, normally are most concerned about prices reflecting, and preferably equaling, the market value of the resources that go into the production of a product; or more simply stated, they think that price should equal marginal production cost. However, many other individuals would no doubt be sympathetic to the concept of price reflecting the value of the product to the users, and they might argue that the total value of a library copy of a journal that is read by many readers is greater than the value of a personal copy that is read only by an individual subscriber. Therefore, they would claim that the library copy ought to sell for a higher price. This argument gains more strength if the readers of the library copy are able to make inexpensive personal photocopies of journal articles.

If one agrees with the latter point of view and employs it as a justification for price discrimination, the logical extension is that a journal pricing system based on expected usage should exist. Publishers could charge college and university libraries according to the number of expected users. This number could be estimated easily from the undergraduate and graduate enrollments, with graduate enrollments weighted more heavily in a simple pricing formula. One can argue the fine points of such a pricing system (e.g., should university or program en- 
rollments be employed?), but enrollment data are normally available to library administrators who could then supply them to publishers. Although such a system would not be perfectly fair, it would be considerably more equitable than the current two-price system which greatly disadvantages small college libraries with limited budgets that make more limited use of library journals than large research libraries which pay the same price. Simply basing journal prices on readily available total institutional enrollments (perhaps using enrollment intervals) would be more equitable than the current twoprice system, for which there is little equity-based justification. Indeed, the advent of the electronic journal, with the possibility that its pricing will eventually be based strictly according to usage, may lead to the most equitable pricing system as well as the most efficient use of society's resources. Subscribers can be charged for and will receive only the articles they plan to read, saving resources for both producer and consumer. Charges will reflect the number of readers because each reader will be charged individually. Extensive pay-per-use operations are already in place in many libraries.

\section{Industry Structure and Unique Industry Characteristics}

Given the preceding criticism of much of the economic analysis that researchers have carried out to date on the journal industry, the next logical step is to describe the actual economic structure of this industry. More to the point, what is there in the structure and conduct of this industry that makes it perform the way it does?

First, there appears to be a great deal of monopoly power in this industry, although it is not a natural monopoly. ${ }^{27,28}$ Given the uniqueness of individual journal articles and the existence of copyright laws, there appears to be no direct competition among publishers of different journals in the same academic field. Ev- ery issue of every journal is unique. Because authors of research articles are normally expected to read and cite all articles relevant to their research topics, they cannot omit reading an article in favor of a close substitute. There are no substitutes, unlike the magazine market, for example. Whereas Newsweek, Time, and U.S. News compete with and are considered to be substitutes for each other by most news magazine subscribers, the American Economic Review and the Journal of Political Economy are not really competitors. Libraries must buy both journals, and economic researchers must read the relevant articles in both. Therefore, every publisher of a major journal should be con-

Monopoly and third-party payment are the two key characteristics that explain pricing behavior and the apparently high price levels in the academic journal industry.

sidered a monopolist. In this sense, the journal publishing industry is truly unique. There is a captive audience for all major journals.

A second important and somewhat unique characteristic of the industry is that, to the extent that journal marketing is primarily directed at librarians, the demander and ultimate user is neither ordering nor paying for the product; those activities rest with the library. ${ }^{29}$ The importance of this characteristic can be seen by looking at a similar industry-pharmaceuticals. Many, if not most, people who use prescription drugs do not pay directly for them; insurance companies do. It is no coincidence that prescription drug prices are high; the rate of drug price inflation persistently has been above the United States's average rate of inflation, and the drug industry consistently has had average profits two to three times the rate of return of the average American manufacturing industry. Demand for a product will always be greater when the 
user is spending someone else's money. Although this point is not made in many standard economics texts, it is acknowledged widely by economists. Professional journals and pharmaceuticals are two of the few industries in which this purchasing situation exists, along with other sectors of the health care industry.

Monopoly and third-party payment are the two key characteristics that explain pricing behavior and the apparently high price levels in the academic journal industry. A third unique characteristic is that the industry contains many nonprofit producers who "bundle" journals along with other products as part of membership packages in a manner that law enforcement agencies might consider to be an antitrust violation in profit-oriented industries. Membership and the purchase of several journals become essentially an all-or-nothing proposition, hence the term bundling. This practice also makes it difficult for researchers to determine the individual journal prices. The American Economic Association, for example, includes three major journals (thirteen issues) as part of an annual association membership for fees ranging between $\$ 47$ and \$66 in 1994 (depending on the member's income level). Members can save six dollars by refusing one of the journals, but they cannot save more than six dollars, although the association claims that 30 percent of the membership fee goes to pay for each of the three journals.

\section{The Effect of Structural \\ Characteristics on Performance}

Given these unique structural characteristics, the authors next attempted to determine what effect they have on performance in the academic journal industry. The authors know that price discrimination requires the presence of monopoly power, or otherwise competitors will undercut the high prices charged to the buyers who are being discriminated against-in this case, libraries. The exist- ence of monopoly power also means that if the price discrimination does breed ill will, there may be little that the buyers can do. This is especially true if the buyers (i.e., libraries) are not the ones requesting and using the product. In this market, ill will clearly exists, but it rarely affects the pricing behavior of the sellers unless it is accompanied by hostile actions on the part of libraries. Therefore, it should not be surprising that there has been a persistent tendency for the most expensive journals to have the largestpercentage price increases. ${ }^{30}$

As several writers note, the monopoly power of journal publishers leads to highly inelastic demand from research libraries, in part because faculty demand, and will not accept substitutes for, specific journals which the faculty do not pay for and for which they rarely know the price. ${ }^{31-34}$ Meanwhile, individual subscriber demand is much more elastic regarding purchasing personal subscriptions because individual subscribers can photocopy articles at little or no cost in their libraries or obtain copies through interlibrary loan, whereas personal subscriptions usually must be paid for out of their own household budgets.

Hence, a perfect scenario exists for publishers to implement price discrimination. Publishers' claims that the large number of readers of library copies of journals justifies a higher price should be disregarded. One might draw a parallel between this situation and the American Medical Association's efforts to justify high prices charged by medical doctors on the basis that they must invest so many years in training. Such moral justification has nothing to do with the price level or pricing structure. A firm can only charge high prices and price-discriminate if market conditions allow. The equity-based arguments of the publishers, whether they provide moral justification for the pricing practices or not, are beside the point. Photocopy pricing and quality may be correlated over time with the extent of 
price discrimination in journal pricing as S.J. Leibowitz suggested, in that the availability of inexpensive, good-quality photocopies of library journal articles may keep personal journal subscription prices low. However, this cannot explain fully why price discrimination against libraries exists to the extent that it does in the journal publishing industry. ${ }^{35}$

Similarly, much of the price differences among journals in different academic disciplines appears to be the result of price discrimination by discipline rather than differences in production cost, although the supporting evidence for this statement is limited and further investigation is needed. ${ }^{36,37}$ Journals in the natural sciences and engineering fields are far more expensive than journals in other fields. When seeking an explanation, one often hears that the printing cost of the mathematical symbols and illustrations is the reason for the high price. Yet, the price differentials appear to be far higher than printing cost differentials would seem to justify, and art journals, with expensive illustrations, are not particularly high priced. $^{38}$

The answer to the question on price differences by discipline may be much simpler and quite consistent with what economic theory would predict. Publishers charge more for natural science journals because they are able to do so. As one commercial publisher marketing executive (who prefers anonymity) of a major for-profit journal publisher stated in an interview, publishers charge higher prices for science journals because natural science research is considered more urgent and is far better funded than other types of research. Scientists need these journals, and they have funds to pay for them. It is a simple case of maximizing profit by charging higher prices in markets where demand is inelastic. It should also not be surprising that commercial publishers are more dominant in science and engineering than in other disciplines. One study found that commercial firms published over 63 percent of the chemistry journals that a particular major research library purchased, and these firms received almost 80 percent of the subscription money paid for chemistry journals by that library. ${ }^{39}$

Although commercial publishers claim that their prices and profits are not excessive, there is good reason to believe that the commercial journal publishing industry is highly profitable and has become more profitable during the past two decades of rapid price increases and increasing price discrimination. ${ }^{40}$ Economic Consulting Services (ECS) points to "the rapidly growing disparity between the costs of publishing and subscription prices charged to libraries." 41 The aforementioned journal marketing executive pointed out the ideal market situation in which commercial journal publishers exist, despite facing rapidly rising costs. They not only have a monopoly, but their customer base is prepaid and virtually guaranteed for years into the future. The publishers know exactly how many copies to print, incur no debt up front, receive no returns from bookstores, and never have to pay for a second press run. In many ways, the journal publishing business is far more lucrative than the book

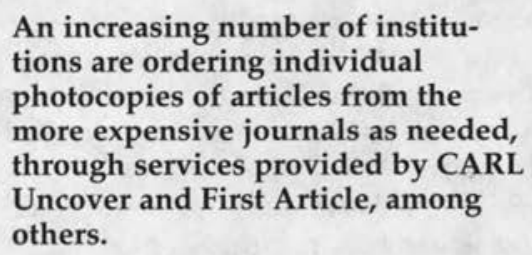

publishing business, he noted. A quote from an interview with the late Robert Maxwell, former owner of Pergamon Journals, in which Maxwell called his journal operations a "cash generator twice over," supports the view of the marketing executive. ${ }^{42}$

When asked to explain the disparity between library and individual subscription prices, the marketing executive's re- 
sponse was simply that he believed commercial publishers charge the maximum that they can get. They know that individuals will not pay the prices that libraries are charged. This is the same conclusion that noted economist Fritz Machlup reached regarding the pricing strategies of scholarly book publishers almost two decades ago. ${ }^{43}$

\section{Policy Recommendations-What Libraries Should Do}

Economists offer a variety of recommendations to libraries based on their analyses. Unfortunately, not all of them are practical. Rather than criticize the impractical recommendations of others, the authors will see what their analysis suggests.

Because the journal pricing problem stems from the existence of monopoly power, the authors first considered ways of dealing with such power. Society has several means of dealing with monopoly situations. Two of these, government ownership and economic regulation such as government-imposed price ceilings, are impractical because the federal government is not about to take over journal publishing firms or begin regulating their prices.

A third method of dealing with a monopoly is to create competition for the monopolist by finding or creating a substitute product. This could involve finding ways to meet the demand for particular journal articles without having the library buy the journals. A few colleges appear to be purchasing alternative journals instead of those with the highest prices, but this is not a feasible solution for research libraries. An increasing number of institutions are ordering individual photocopies of articles from the more expensive journals as needed, through services provided by CARL Uncover and First Article, among others. However, commercial journal publishers could set the copying fees at levels that will maximize their profits, making potential long- term savings from this alternative problematic.

Publishers should be told when they lose customers as a result of their high prices. They must realize that, despite monopoly power, demand is relatively elastic as prices rise. If a subscription is cancelled because of price or budgetary problems, publishers should be informed as to the reason, even if it is done with a form letter. Some researchers believe that publishers may finally be starting to receive this message from the "massive serials cancellations programs undertaken by research libraries" in the United States over the past few years. ${ }^{44}$

In a study commissioned by the Association of Research Libraries (ARL), ECS suggested that professional associations create new journals as nonprofit alternatives to commercial publishers and that these associations and the ARL should also encourage low-price profit-seeking publishers to create additional journals. ${ }^{45,46}$ Others have called for universities as well as learned professional associations to enter the journal publishing business. ${ }^{47}$ Many economists believe that in a free market system, in an industry where excessive profits are being made, new firms will be drawn into the industry because of the strong profit incentives, even if they must overcome the considerable monopoly power of the highly profitable existing firms. That is usually true, but sometimes it takes several decades for the new entrants to gain a foothold. The authors therefore encourage the ARL to facilitate this process, and the best prospects for entry may be small established American commercial publishers who are willing to work with professional associations that can guarantee a market for their products.

ARL has, thus far, taken a slightly different approach to the journal pricing problem. In a recent collaborative effort, the Association of American Universities (AAU) and the ARL set up three task forces to: (1) study acquisition and distri- 
bution of foreign language and area studies materials; (2) develop a national strategy for managing scientific and technical information; and (3) study intellectual property rights in an electronic environment. Those task forces, recognizing the growing monopoly power of a few European publishers and the extent to which they have a captive university market, concluded that additional competition must be "injected" into the journal market. ${ }^{48}$ Task force members believe that the advent of electronic journals and databases provides new opportunities for low-cost journal market entry by professional societies and university presses with electronic links to regional and national distribution centers where all scholars may access any journals from their desktop computers. ${ }^{49}$

Closely tied to these suggestions, the task forces noted, is the need to change copyright practices so that the federal government, universities, and faculty members somehow retain copyright control over the work that they either fund or do themselves. This is in contrast to the current practice of signing over copyright ownership to the journal publishers. The task forces recognized that, as noted above, the lower costs of electronic publishing will not be passed on as lower prices to subscribers by commercial publishers unless the competitive situation is changed. However, as the task forces also noted, such changes will require cooperation among scholars, universities, and the federal government, who will have to present a united front in order to force publishers to give up copyright control of journal articles. These changes may also require modification of university scholarship requirements for tenure and promotion. Tenure and promotion committees must be willing to recognize fully publications in the new journals, both electronic and print, that university presses and others are being encouraged to start. Gaining such total cooperation, if that is possible, would require a great deal of work by a powerful central coordinating organization, as the task forces recognized. This idea essentially encompasses another economic solution to the monopoly problem - bilateral monopoly.

Long employed by union organizers, bilateral monopoly consists of meeting monopoly power with opposing monopoly power. Industrial organization economist H. Craig Petersen, in an excellent study of factors affecting journal pricing, states, "Another group that could influence journal pricing is library associations." ${ }^{50} \mathrm{He}$ then suggests that "at the very least, publishers whose prices are significantly higher than charges for comparable publications should be asked to justify their pricing practices by providing detailed information on costs." ${ }^{51}$ The authors concur, but take the suggestion further. As organizations representing the customers who are discriminated against, the ALA and ARL, with the help of the AAU, can act as monopoly buyers, developing cooperative purchasing arrangements (which has begun to occur through other organizations), as suggested by Chressanthis and Chressanthis, or employing threats of collective action such as boycotts against the publishers who are the greatest offenders in setting high or discriminatory prices that they cannot or will not attempt to justify. ${ }^{52}$ The ECS study suggests that the ARL should act as a lobbyist to find new publication channels. ${ }^{53}$ That is not much different from putting the squeeze on offending publishers directly. The ARL-AAU task force reports have similar implications. In essence, carrying out the recommendations hinges on the coordination of a massive cooperative effort by scholars, government, universities, and university presses that amounts to the formation of a united front or effective monopoly to wrest control of copyrights and scholarly publication from a small group of commercial publishers. This solution could work, but the obstacles are many, not the least of which is the magnitude of the necessary coordina- 
tion effort and the need to change the academic prestige and reward system to include electronic, and other less expensive journals.

As noted above, the second problem characteristic in the journal market is "third-party payment." The demanders and users are not paying for the journals that they request and use. In dealing with that problem, the following suggestion will have positive results ultimately. Give the researchers who request and use the journals an economic incentive to care about the prices and the library expenditures in this area. Force them to deal with the library's budget problems by providing a budget for journals in their disciplines and supplying them with a list of subscriptions and prices. Let them help to choose which journals they want within the library's budget constraint. If they refuse involvement, library admin-

\section{Price discrimination is not illegal, but neither are consumers' attempts to avoid or combat it. Price discrimi- nation and rapidly rising prices are breeding ill will among library administrators, and it might be helpful to their cause if such feelings were shared by the faculty who read and publish in the journals.}

istrators will make the decisions and faculty members will have few grounds for complaint. The tighter the budget constraints, the more interested they should be in dealing with the problem as subscriptions are cancelled. Once again, note Petersen's findings that "rapid price increases are not inevitable. ...," and "If prices of certain journals become too high, scholars could use their professional associations to establish other, less expensive publications. The problem is that scholars have little incentive to do so." 54 Jean Walstrom Haley and James Talaga, in a survey of libraries' efforts to deal with the journal price inflation problem, found that university librarians reported that shifting journal selection to faculty, cancelling subscriptions in protest of price increases, and filing individual complaints with publishers were thought to be the most successful remedies by those who had employed them, but few libraries had done so. ${ }^{55}$ Haley and Talaga also suggested attempting to negotiate prices with publishers and sharing resources among libraries.

ECS suggested involving university leaders and professional societies in this effort. ${ }^{56}$ The key is to provide the right incentives to all parties, the demanders as well as the publishers. Journal users must think they have a real stake in the outcome of the process. Although the effect of involving these additional parties cannot be forecast precisely, providing the correct incentives will usually result in positive outcomes, whether they be new, less expensive journals, as Petersen, ECS, and AAU-ARL suggested, or lower prices for existing journals.

In addition, consumer groups can try to counter price discrimination by changing one or more of the aforementioned six conditions necessary to its maintenance. Perhaps effective reseller markets may be established. Despite publishers' printed statements that individual subscribers may not pass their journals on to libraries for other readers, that proscription is of dubious legal validity and publishers have never tested it in court. The authors believe publishers are not anxious to test it. Illegal duplication of a product for profit is one matter. Selling or letting others use a product that you purchased is certainly another matter, and this practice has never been illegal in the United States.

Price discrimination is not illegal, but neither are consumers' attempts to avoid or combat it. Price discrimination and rapidly rising prices are breeding ill will among library administrators, and it might be helpful to their cause if such feelings were shared by the faculty who read 
and publish in the journals. To that end, the ARL should continue to publish price indices and publicize the price differentials between low-priced and high-priced publishers.

Ironically, some publishers claim, and researchers acknowledge, that subscription cancellations, which appear to have sharply accelerated recently, force them to raise prices further to maintain profit margins. ${ }^{57-59}$ Although such actions are neither unheard of nor unjustified, they only succeed if the remaining demand is inelastic so that further price increases do not lead to additional cancellations. ${ }^{60}$ Such inelasticity is a further indication of monopoly power, thereby leading to the conclusion that journal publishers think that they have considerable monopoly power despite the subscription cancellations.

\section{Summary and Conclusions}

An economic analysis of the journal industry indicates that high and discriminatory prices result from the existence of monopoly power among publishers. University and library administrators can alleviate this problem in several ways: (1) by providing journal users with an incentive for keeping prices lower; (2) by encouraging library organizations and university consortia to exploit their potential monopsony (i.e., a buying monopoly) power into a bilateral monopoly situation; and (3) by attempting to create and demonstrate high elasticity of demand for journals in any way possible. Even if some degree of price discrimination is justified by consumer equity considerations, the current pricing situation is far from equitable and can be improved if publishers can be coerced to change their pricing practices. Meanwhile, efficiency and resource allocation considerations, which are usually of the utmost importance to "normative" economists (i.e., those interested in efficient use of society's resources), appear to favor holding journal prices to libraries down to levels close to marginal production cost (including a reasonable profit) in order to promote the shared usage that takes place in libraries as opposed to printing an individual copy for each user. Journal price inflation has exceeded greatly the rate of increase in the consumer price index in the past quarter century. There is evidence that the greatest extent of high markups and price discrimination is centered in a few commercial publishing firms, primarily located in Western Europe, and in a few disciplines. ${ }^{61-65}$ The pricing practices and profitability of these firms need to be explored further to determine whether there is any cost-based justification for their high prices and to develop a more complete understanding of the journal price problem, for recent data show that the problem is not simply going to disappear. ${ }^{66}$ Nor should society expect that to happen.

\section{Notes}

1. Kenneth E. Marks and Steven P. Nielsen, "A Longitudinal Study of Journal Prices in a Research Library," Serials Librarian 19 (1991): 105-35.

2. Lee Ketcham and Kathleen Born, "Projecting Serials Costs: Banking on the Past to Buy for the Future, Periodical Price Survey, 1994," Library Journal 119 (Apr. 15, 1994): 44-50.

3. Association of Research Libraries, Report of the ARL Serials Prices Project (Washington, D.C.: ARL, 1989).

4. Economic Consulting Services, Inc., "A Study of Trends in Average Prices and Costs of Certain Serials over Time," in Report of the ARL Serials Prices Project (Washington, D.C.: ARL, 1989).

5. David W. Lewis, "Economics of the Scholarly Journal," College \& Research Libraries 50 (Nov. 1989): 674-88.

6. Bruce R. Kingma and Philip B. Eppard, "Journal Price Escalation and the Market for Information: The Librarians' Solution," College \& Research Libraries 53 (Nov. 1992): 523-35.

7. ECS, "A Study of Trends in Average Prices and Costs of Certain Serials over Time." 
8. Marks and Nielsen, "A Longitudinal Study of Journal Prices in a Research Library"

9. H. Craig Petersen, "The Economics of Economics Journals: A Statistical Analysis of Pricing Practices by Publishers," College \& Research Libraries 53 (Mar. 1992): 176-81.

10. Lewis, "Economics of the Scholarly Journal"

11. ECS, "A Study of Trends in Average Prices and Costs of Certain Serials over Time."

12. Kingma and Eppard, "Journal Price Escalation and the Market for Information"

13. Fritz Machlup, "Publishing Scholarly Books and Journals: Is It Economically Viable?" Journal of Political Economy 85 (Feb. 1977): 217-25.

14. Charles Hamaker and Deana Astle, "Recent Price Patterns in British Journal Publishing," Library Acquisitions: Practice and Theory 8 (1984): 225-32.

15. Patrick Joyce and Thomas Merz, "Price Discrimination in Academic Journals," Library Quarterly 55 (July 1985): 273-83.

16. Jean Walstrom Haley and James Talaga, "Academic Library Responses to Journal Price Discrimination," College \& Research Libraries 53 (Jan. 1992): 61-70.

17. George A. Chressanthis and June D. Chressanthis, "Publisher Monopoly Power and ThirdDegree Price Discrimination of Scholarly Journals," Technical Services Quarterly 11, no. 2 (1993): 13-36.

18. Joyce and Merz, "Price Discrimination in Academic Journals"

19. Deana Astle and Charles Hamaker, "Pricing by Geography: British Journal Pricing 1986, Including Developments in Other Countries," Library Acquisitions: Practice and Theory 10 (1986): $165-81$.

20. H. Craig Petersen, "University Libraries and Pricing Practices by Publishers of Scholarly Journals," Research in Higher Education 31 (1990): 307-314.

21. Chressanthis and Chressanthis, "Publisher Monopoly Power and Third-Degree Price Discrimination of Scholarly Journals"

22. Joyce and Merz, "Price Discrimination in Academic Journals"

23. H. Craig Petersen, "Variations in Journal Prices: A Statistical Analysis," Serials Librarian 17 (1989): 1-9.

24. Petersen, "University Libraries and Pricing Practices by Publishers of Scholarly Journals"

25. One example of such an article is James Talaga and Jean Walstrom Haley, "Marketing Theory Applied to Price Discrimination in Journals," Journal of Academic Librarianship 16 (Jan. 1991): 348-51.

26. Edward A. Dyl, "A Note on Price Discrimination by Academic Journals," Library Quarterly 53 (Apr. 1983): 161-68.

27. Richard Dougherty and Brenda Johnson, "Periodical Price Escalation: A Library Response," Library Journal 113 (May 15, 1988): 27-29.

28. Association of American Universities in collaboration with the Association of Research Libraries, Reports of the AAU Task Forces on Acquisition and Distribution of Foreign Language and Area Studies Materials, A National Strategy for Managing Scientific and Technological Information and Intellectual Property Rights in an Electronic Environment, (Washington, D.C.: ARL, 1994).

29. Machlup, "Publishing Scholarly Books and Journals."

30. Anthony M. Cummings, Marcia L. Witte, William G. Bowen, Laura O. Lazarus, and Richard H. Ekman, University Libraries and Scholarly Communication, (Washington, D.C.: ARL, 1992).

31. Richard De Genaro, "Escalating Journal Prices: Time to Fight Back," American Libraries 8 (Feb. 1977): 69-74.

32. James C. Thompson, "Journal Costs: Perception and Reality in the Dialogue," College \& Research Libraries 49 (Nov. 1988): 481-82.

33. Christian M. Boissonnas, "ALA/ACRL Journal Prices in Academic Libraries Discussion Group. Copyright: The TRLN Document, University Policy Regarding Faculty Publications in Scientific and Technical Scholarly Journals,'" Library Acquisitions: Practice and Theory 18 (spring 1994): 99-101.

34. AAU in collaboration with the ARL, Reports of the AAU Task Forces.

35. S. J. Leibowitz, "Copying and Indirect Appropriability: Photocopying of Journals," Journal of Political Economy 93 (1985): 945-57.

36. Petersen, "Variations in Journal Prices," 1-9.

37. Ketcham and Born, "Projecting Serials Costs."

38. Petersen, "University Libraries and Pricing Practices by Publishers of Scholarly Journals."

39. John O. Christiansen, "Cost of Chemistry Journals to One Academic Library," Serials Review 18 (fall 1992): 19-36.

40. For examples of such claims, see John Tagler, "Counterpoint: A Publisher's Perspective," American Libraries 19 (Oct. 1988): 767. 
41. ESC, "A Study of Trends in Average Prices and Costs of Certain Serials over Time," 20.

42. Reprinted in James C. Thompson, "Journal Costs: Perception and Reality in the Dialogue."

The citation for the quote from Robert Maxwell is Global Business, 41+ (spring 1988).

43. Machlup, "Publishing Scholarly Books and Journals."

44. Ketcham and Born, "Projecting Serials Costs."

45. ECS, "A Study of Trends in Average Prices and Costs of Certain Serials over Time."

46. Ibid.

47. Paul McCarthy, "Serial Killers: Academic Libraries Respond to Soaring Costs," Library Journal 119 (June 15, 1994): 41-44.

48. AAU in collaboration with the ARL, Reports of the AAU Task Forces.

49. Ibid.

50. Petersen, "The Economics of Economics Journals."

51. Ibid., 180.

52. George A. Chressanthis and June D. Chressanthis, "Publisher Monopoly Power and Third-

Degree Price Discrimination of Scholarly Journals," 13-36.

53. ECS, "A Study of Trends in Average Prices and Costs of Certain Serials over Time."

54. Petersen, "The Economics of Economics Journals," 180.

55. Haley and Talaga, "Academic Library Responses to Journal Price Discrimination,"

56. ECS, "A Study of Trends in Average Prices and Costs of Certain Serials over Time."

57. Janet H. Fisher, John Tagler, Beth J. Shapiro, and Mary Beth Vanderpoorten, "The Balance

Point: Perspectives on Firm Serials Prices," Serials Review 19 (winter 1993): 63-72.

58. ECS, "A Study of Trends in Average Prices and Costs of Certain Serials over Time."

59. Ketcham and Born, "Projecting Serials Costs."

60. Petersen, "The Economics of Economics Journals," 176-81.

61. Astle and Hamaker, "Pricing by Geography."

62. ECS, "A Study of Trends in Average Prices and Costs of Certain Serials over Time."

63. Petersen, "Variations in Journal Prices."

64. Petersen, "The Economics of Economics Journals."

65. AAU in collaboration with the ARL, Reports of the AAU Task Forces.

66. Ketcham and Born, "Projecting Serials Costs."

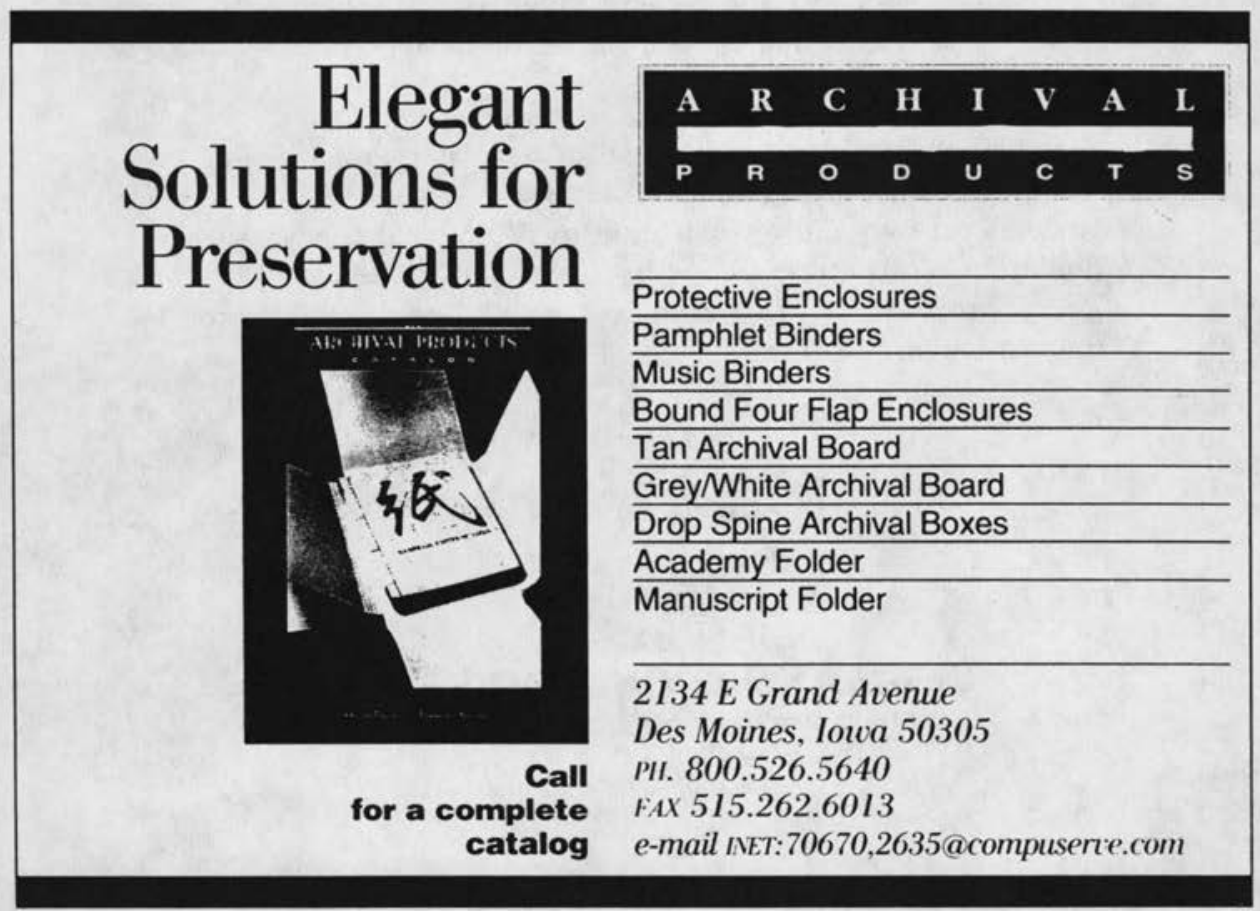




\section{A New Service on the Information Superhighway}

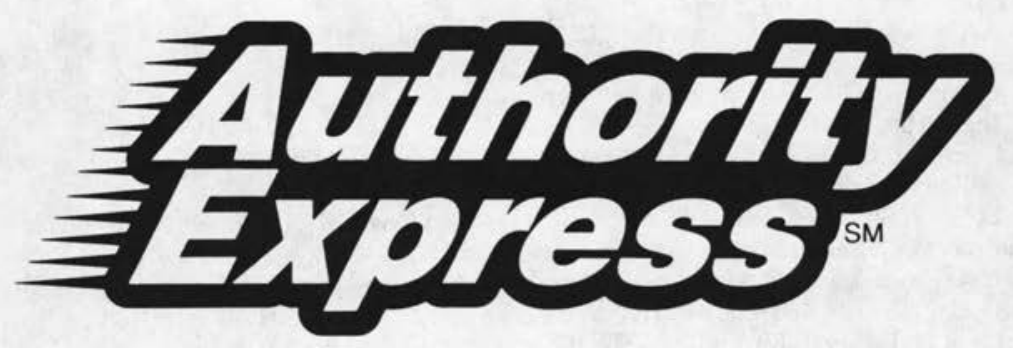

If you have been searching for an easy way to authority control your library's current cataloging, try LTI's Authority Express service.

With Authority Express, a library uses the Internet to transmit a file of newly cataloged bibliographic records to LTI (via FTP). Overnight, LTI processes the records through its state-of-the-art authority control system. Then, at the library's convenience, it logs into LTI's FTP server to retrieve fully authorized catalog records, along with linked LC name and subject authority records.

\section{Authority Express}

- Keeps authority control current at an affordable price

- Integrates easily into existing workflows

- Lowers cost by reducing staff time spent on catalog maintenance

- Provides next-day turn around for up to 5,000 catalog records

- Accepts records for processing even if LTI did not perform the original authority control

"Authority Control for the 21st Century"

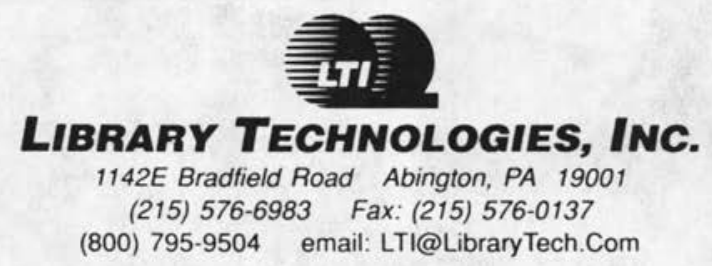

